\title{
OPTIMASI TUTUPAN LAHAN RUANG TERBUKA HIJAU PUBLIK KOTA KOTAMOBAGU
}

\author{
Priawanto Kasim \\ Bobby Polii \\ Zetly Tamod
}

\begin{abstract}
This study was conducted to (1) identify the public green opened space based on covering area in Kotamobagu city and (2) analyze the optimization of development for the public green opened space in Kotamobagu city. Method used in this study was the mix method. The mix method was applicated to study and analyze the index of covering area based on size of existing of the public green opened space. This existing public green opened space would define direction of continouos public green opened space development in Kotamobagu city. Result of the study showed that (1) the size of public green opened space in Kotamobagu city was 1.059 ha with the covering area index of 16 percents. The size of public green opened space in Kotamobagu city consists of several types of public green opened spaces, which were not optimally managed such as those at Pobundayan city parks, Gelora Ambang city parks and Bonawang city forest. (2) Development of public green opened space in Kotamobagu city was focused on minimum size target of 20 percents from entired size of Kotamobagu areas as the indicator of green city standard. The potential locations for size development were including the areas of plantation, city forest and river common border of $50 \mathrm{~m}$.
\end{abstract}

Keywords: area covering optimization, green opened space, Kotamobagu City

\begin{abstract}
ABSTRAK
Penelitian ini bertujuan (1) mengidentifikasi Ruang Terbuka Hijau (RTH) publik berdasarkan tutupan lahan di wilayah Kota Kotamobagu serta (2) menganalisis untuk mengoptimalisasi pengembangan tutupan lahan RTH publik di Kota Kotamobagu. Metode yang digunakan dalam penelitian ini adalah metode kombinasi (Mix method). Penggunaan mix method pada penelitian ini untuk mengkaji dan menganalisis indeks tutupan lahan berdasarkan luas lahan RTH publik eksisting, agar dapat menentukan arah pengembangan lebih lanjut. Hasil penelitian menunjukkan bahwa (1) RTH publik Kota Kotamobagu memiliki luas 1.059 ha dengan indeks tutupan lahan (16\%), yang didalamnya terdiri dari beberapa jenis RTH publik eksisting di Kota Kotamobagu yang pengelolaanya belum optimal seperti Taman Kota Pobundayan, Taman Kota Gelora Ambang, dan Hutan Kota Bonawang. (2) Untuk Pengembangan RTH publik di Kota Kotamobagu dititikberatkan pada pemenuhan luas minimal 20\% dari luas wilayah sebagai salah satu indikator kota hijau. Lokasi yang dianggap berpotensi untuk dikembangkan dari segi luas adalah wilayah perkebunan, hutan kota dan sempadan sungai $50 \mathrm{~m}$.
\end{abstract}

Kata kunci: optimasi, tutupan lahan, ruang terbuka hijau, Kota Kotamobagu 


\section{PENDAHULUAN}

\section{Latar Belakang}

Isu lingkungan terkait dengan terjadinya pemanasan global dalam beberapa dekade terakhir ini telah menjadi pusat perhatian bagi seluruh masyarakat di dunia. Isu pemanasan global ini merupakan ancaman bagi kelangsungan kehidupan berbagai ekosistem yang ada di bumi. Pemanasan global atau yang juga biasa dikenal sebagai efek rumah kaca disebabkan karena semakin besarnya konsentrasi gas-gas rumah kaca yang terdapat di atmosfer. Salah satu upaya yang dapat dilakukan untuk meminimalisir dampak dari terjadinya pemanasan global yaitu melalui penyediaan Ruang Terbuka Hijau (RTH). Dalam Peraturan Daerah Kota Kotamobagu Nomor 08 Tahun 2014 pasal 31 ayat 3 menerangkan bahwa terdapat 15 jenis RTH Publik yang ada di Kota Kotamobagu dengan luas wilayah keseluruhan 2.697,79 ha. Salah satu tujuan ruang terbuka hijau dibangun adalah peningkatan kualitas lingkungan (Environmental Enhancement), kualitas lingkungan terbangun dari ruang terbuka hijau sebagai paru-paru kota. Vegetasi dan penghijauan berkontribusi terhadap kualitas udara di wilayah tersebut. Adapun salah satu dari tiga indikator dalam menentukan kualitas lingkungan dalam suatu wilayah adalah tutupan lahan. Suatu daerah dengan kualitas lingkungan baik jika indikator tutupan lahan mencapai 40\%. Program Pengembangan Kota Hijau (P2KH) yang telah berlangsung selama empat tahun dengan konsep kota hijau difokuskan pada RTH publik Kota Kotamobagu perlu diidentifikasi dan dianalisis dari segi tutupan lahan guna mengetahui kualitas lingkungan yang ada di Kota Kotamobagu serta pengembangan RTH publik kedepannya.

\section{Rumusan Masalah}

Berdasarkan uraian latar belakang di atas, maka permasalahan dapat dirumuskan sebagai berikut:

1. Bagaimana kondisi tutupan lahan RTH publik saat ini yang terbesar di wilayah Kota Kotamobagu?

2. Bagaimana upaya pengembangan tutupan lahan RTH publik di Kota Kotamobagu berdasarkan RTRW Kota Kotamobagu?

\section{Tujuan Penelitian}

1. Mengidentifikasi dan menganalisis RTH publik berdasarkan tutupan lahan di wilayah Kota Kotamobagu.

2. Menganalisis untuk mengoptimalisasi pengembangan tutupan lahan RTH publik di wilayah Kota Kotamobagu.

\section{Manfaat Penelitian}

1. Menjaga konservasi dan keseimbangan ekosistem lingkungan Kota Kotamobagu

2. Mewujudkan keseimbangan antara lingkungan alami lingkungan buatan di Kota Kotamobagu

3. Meningkatkan kualitas lingkungan perkotaan yang sehat, indah, bersih dan nyaman di Kota Kotamobagu

4. Memberi masukan pada pemerintah daerah mengenai kebijakan pengelolaan ruang terbuka hijau di Kota Kotamobagu

5. Memberikan kontribusi teoritik mengenai kebijakan pengelolaan ruang terbuka hijau perkotaan

6. Mebagai salah satu sumber data dan informasi bagi pengembangan penelitian dibidang kehutanan dan ilmu lingkungan selanjutnya

7. Memperluas khasanah pengetahuan bagi pengembangan lingkungan hidup

\section{METODOLOGI PENELITIAN}

\section{Waktu Dan Tempat Penelitian}

Kegiatan penelitian ini dilaksanakan di Kawasan RTH publik Kota Kotamobagu yang terbesar di empat Kecamatan yakni Kecamatan Kota Kotamobagu Timur, Kotamobagu Utara dan Kotamobagu Selatan Provinsi Sulawesi Utara. Penelitian berlangsung mulai dari bulan Agustus sampai September 2017.

\section{Metode Penelitian}

Metode yang digunakan dalam penelitian ini adalah metode kombinasi (Mix method). Mix method merupakan pendekatan penelitian yang mengkombinasikan atau menggabungkan bentuk kualitatif dan kuantitatif. Tujuan penggunaan mix method pada penelitian ini untuk mengkaji dan menganalisis indeks tutupan lahan berdasarkan 
luas lahan RTH publik eksisting, agar dapat menentukan arah pengembangan lebih lanjut.

\section{Teknik Pengumpulan Data}

Teknik pengumpulan data terdiri dari:

1. Pengamatan atau observasi;

Observasi dalam penelitian kualitatif sebagaimana yang diungkapkan oleh Sutrisno Hadi dalam Sugiyono (2013: 145) bahwa, observasi merupakan suatu proses yang komleks, suatu proses yang tersusun dari berbagai proses biologis dan psikhologis. Dua di antara yang terpenting adalah proses-proses pengamatan dan ingatan. observasi dilakukan untuk mengetahui kondisi RTH publik Kota Kotamobagu, mengukur luas lahan dan mengidentifikasi jenis-jenis RTH publik yang eksisting.

\section{Studi Dokumen}

Study dokumen merupakan suatu metode atau teknik yang digunakan dalam penelitian kualitatif untuk mengungkapkan, mencari berbagai informasi dari sumber-sumber yang berkaitan dengan masalah penelitian. Menurut Sugiyono (2013: 240), dokumen merupakan catatan peristiwa yang sudah berlalu. Dokumen bisa berbentuk tulisan, gambar, atau karya-karya dari seseorang. Studi dokumen merupakan pelengkap dari penggunaan observasi dalam penelitian kualitatif.

\section{Analisis Data}

\section{Analisis Data Kualitatif}

Menurut Sugiyono (2010: 14) metode analisis kualitatif yaitu "Metode penelitian kualitatif itu dilakukan secara insentif, peneliti ikut berpertisipasi lama dilapangan, mencatat secara hati-hati apa yang terjadi, melakukan analisis reflektif terhadap berbagai dokumen yang ditemukan dilapangan, dan membuat laporan penelitian secara mendetail".

\section{Analisis Tutupan Lahan}

Analisis tutupan dan penggunaan lahan merupakan tahapan awal untuk memahami kekurangan suatu area atau objek penelitian.
Melalui bantuan citra satelit dan tehnik penginderaan jauh, fitur-fitur alami dan antropogenik yang tampak dalam citra diekstraksi, dikelompokan, dilakukan groundchek kemudian dianalisis.

\section{HASIL DAN PEMBAHASAN}

\section{Deskripsi Umum Kota Kotamobagu}

Secara astronomis Kota Kotamobagu terletak antara $0^{0} \quad 41^{\prime} 16,29^{\prime \prime}-0^{0} \quad 46^{\prime} 14,8^{\prime \prime}$ Lintang Utara dan $124^{0} 15^{\prime} 9,56^{\prime \prime}-124^{0} 21^{\prime}$ 1,93" Bujur Timur. Kota Kotamobagu secara administratif terbagi kedalam 4 kecamatan dan 33 desa/kelurahan dengan Luas wilayah keseluruhan mencapai $68,09 \mathrm{~km}^{2}$. Sebagai bagian dari wilayah Provinsi Sulawesi Utara maka secara umum Kota Kotamobagu juga beriklim tropis yang dipengaruhi angin muson dengan Suhu udara rata-rata adalah $25,2^{0} \mathrm{C}$. Suhu udara maksimal rata-rata tercatat $30,4^{\circ} \mathrm{C}$ dan suhu udara minimum rata-rata $22,0^{\circ} \mathrm{C}$. Berdasarkan data BPS Tahun 2017, jumlah penduduk Kota Kotamobagu di tahun 2016 mencapai 121.699 jiwa. Tersebar di Kecamatan Kotamobagu Barat 42.608 jiwa, Kecamatan Kotamobagu Utara sebanyak 17.145 jiwa, Kecamatan Kotamobagu Timur sebanyak 29.103 jiwa dan Kecamatan Kotamobagu Selatan sebanyak 32.645 jiwa, dengan arah kebijakan umum pembangunan Kota Kotamobagu diantaranya adalah meningkatan kualitas sumberdaya manusia melalui peningkatan layanan kesehatan dan pendidikan.

\section{Ruang Terbuka Hijau (RTH) Publik di Kota Kotamobagu}

Berdasarkan Rencana Tata Ruang Wilayah Kota Kotamobagu tahun 2014-2034 (RTRW) luas total RTH yang ada di Kota Kotamobagu adalah 4.719,08 hektar atau 69,3\% dari luas wilayah Kota Kotamobagu 68,09 km². Dimana RTH Publik seluas 2.697,38 hektar atau $39,61 \%$ dan RTH Private seluas 2.021,7 hektar atau 29,69\%, dalam hal ini Ruang terbuka hijau di Kota Kotamobagu sudah memenuhi standar, dimana dalam Undang Undang (UU) Nomor 26 Tahun 2007 tentang penataan ruang mensyaratkan ruang terbuka hijau pada wilayah kota paling sedikit 30\% dari luas wilayah kota dapat dilihat pada Tabel 1. 
Tabel 1. RTH Publik Kota Kotamobagu (RTRW 2014)

\begin{tabular}{clcc}
\hline No & Jenis RTH Publik & Luas (Ha) & Persentase (\%) \\
\hline 1 & Taman lingkungan & 35,4 & 1.31 \\
& RT/RW & & \\
2 & Taman kota & 20 & 0.74 \\
3 & Hutan kota & 677 & 25.1 \\
4 & Kebun raya kota & 300 & 11.1 \\
5 & Taman kecamatan & 11,1 & 0.41 \\
6 & Taman resting area & 10,1 & 0.37 \\
7 & Kawasan agrowisata & 555 & 20.6 \\
8 & Median jalan & 6,6 & 0.24 \\
9 & Jalur hijau pada sisi & 288,4 & 10.7 \\
& jalan pan & 13,5 & 0.5 \\
10 & Jalur hijau pada & \\
& pejalan kaki & 107,2 & 3.97 \\
11 & Sempadan sungai & 100,6 & 3.73 \\
12 & Sempadan mata air & 514 & 19.1 \\
13 & Kawasan resapan air & 9 & 0.33 \\
14 & Pemakaman umum & 49,48 & 1.83 \\
15 & Lapangan & & \\
& olahraga/lapangan & & $\mathbf{1 0 0}$ \\
\hline & terbuka & $\mathbf{2 . 6 9 7 , 3 8}$ & \\
\hline & Jumlah & &
\end{tabular}

\section{Kondisi Eksisting RTH Publik di Kota}

\section{Kotamobagu}

Setelah melakukan observasi di lapangan, jenis ruang terbuka hijau publik yang teridentifikasi di Kota Kotamobagu saat ini meliputi taman kota yang terdapat di Kelurahan Kotamobagu, Kelurahan Biga, Kelurahan Pobundayan, Kelurahan Kotobangon, Kelurahan Mogolaing, Kelurahan Molinow dan Kelurahan Mongkonai; Hutan Kota Bonawang yang terdapat di Kelurahan Mongkonai Barat; Taman Makam Pahlawan yang terdapat di Kelurahan Mongkonai Barat; Lapangan terbuka di Kelurahan Mogolaing dan Kelurahan Molinow; Alun-alun Lapangan Kotamobagu di Kelurahan Kotamobagu; jalur hijau; median jalan; serta sempadan sungai di Kelurahan Mongkonai Barat dan Kelurahan Motoboi Besar dapat dilihat pada Tabel 2.

\begin{tabular}{|c|c|c|c|}
\hline No & Jenis RTH Publik Eksisting & Lokasi & Luas (Ha) \\
\hline \multirow[t]{6}{*}{1} & Taman Kota: & & \\
\hline & Taman Kota Kotamobagu & Kel. Kotamobagu & 0,23 \\
\hline & Taman Kota Gelora Ambang & Kel. Biga & 6,83 \\
\hline & Taman Kota Pobundayan & Kel. Pobundayan & 1,096 \\
\hline & Taman Makam Pahlawan & $\begin{array}{l}\text { Kel. Mongkonai } \\
\text { Barat }\end{array}$ & 0,3 \\
\hline & Taman X-Kantor Bupati & Kel. Kotobangon & \\
\hline \multirow[t]{4}{*}{2} & Lapangan Olahraga: & & \\
\hline & $\begin{array}{l}\text { Lapangan Olahraga Kotamobagu } \\
\text { Bokihotinimbang (Alun-alun } \\
\text { kota) }\end{array}$ & Kel. Kotamobagu & 1 \\
\hline & Lapangan Olahraga Mogolaing & Kel. Mogolaing & 0,85 ha \\
\hline & Lapangan Olahraga Molinow & Kel. Molinow & 0,75 \\
\hline 3 & Kawasan Hutan Kota & $\begin{array}{l}\text { Kel. Mongkonai } \\
\text { Barat }\end{array}$ & 25,4 \\
\hline 4 & Kawasan Resapan Air & $\begin{array}{c}\text { Desa Sia } \\
\text { Kel. Motoboi } \\
\text { Besar }\end{array}$ & 15,3 \\
\hline 5 & Jalur Hijau dan Median Jalan & $\begin{array}{l}\text { Jalan utama dalam } \\
\text { kota }\end{array}$ & 288 \\
\hline 6 & Sempadan Sungai & $\begin{array}{l}\text { Kel. Mongkonai } \\
\text { Barat, Kel. } \\
\text { Motoboi Besar }\end{array}$ & 507 \\
\hline \multirow[t]{2}{*}{7} & Kawasan Suaka Alam & Desa Sia & 118,2 \\
\hline & Jumlah & & 1.059 \\
\hline
\end{tabular}

Secara umum, kondisi eksisting ruang terbuka hijau (RTH) yang ada di Kota Kotamobagu cukup bervariasi, sebagian besar merupakan daerah hijau kurang intensif. Dari segi kualitas, strata vegetasi RTH yang ada bervariasi antara strata satu sampai dengan tiga.

\section{Tutupan Lahan}

Tabel 3. Luas Tutupan Lahan RTH Publik Eksisting di Kota Kotamobagu

\begin{tabular}{|c|c|c|c|}
\hline No & $\begin{array}{c}\text { Jenis RTH Publik } \\
\text { Eksisting }\end{array}$ & $\begin{array}{l}\text { Luas } \\
\text { (Ha) }\end{array}$ & $\begin{array}{c}\text { Persentase } \\
\text { Luas Tutupan } \\
\text { Lahan }(\%)\end{array}$ \\
\hline 1 & $\begin{array}{l}\text { Taman Kota: } \\
\text { Taman Kota } \\
\text { Kotamobagu } \\
\text { Taman Kota Gelora } \\
\text { Ambang } \\
\text { Taman Kota Pobundayan } \\
\text { Taman Makam Pahlawan } \\
\text { Taman X-Kantor Bupati }\end{array}$ & $\begin{array}{c}10 \\
0,23 \\
6,82 \\
1,096 \\
0,3 \\
1,81\end{array}$ & 0.94 \\
\hline 2 & $\begin{array}{l}\text { Lapangan Olahraga: } \\
\text { Lapangan Olahraga } \\
\text { Kotamobagu } \\
\text { Bokihotinimbang (Alun- } \\
\text { alun kota) } \\
\text { Lapangan Olahraga } \\
\text { Mogolaing } \\
\text { Lapangan Olahraga } \\
\text { Molinow }\end{array}$ & $\begin{array}{c}2,6 \\
1 \\
\\
0,85 \\
0,75\end{array}$ & 0.25 \\
\hline 3 & Kawasan Hutan Kota & 25,4 & 2.4 \\
\hline 4 & Kawasan Resapan Air & 15,3 & 1.4 \\
\hline 5 & $\begin{array}{l}\text { Jalur Hijau dan Median } \\
\text { Jalan }\end{array}$ & 288 & 27.2 \\
\hline 6 & $\begin{array}{l}\text { Sempadan Sungai dan } \\
\text { Mata Air }\end{array}$ & 544 & 50.2 \\
\hline 7 & Kawasan Suaka Alam & $\frac{186,2}{1059}$ & $\frac{17.6}{100}$ \\
\hline
\end{tabular}

Berdasarkan luas tutupan lahan pada Tabel 3 di atas, RTH publik eksisting yang ada di Kota Kotamobagu secara keseluruhan memiliki luas \pm 1.059 ha. Sehingga Indeks Tutupan Lahan yang diperoleh dari hasil analsis ITH yaitu $16 \%$. Kondisi Indeks Tutupan Lahan RTH publik eksisting di Kota Kotamobagu selengkapnya dapat dilihat Tabel 4 dan rincian ITH untuk masing-masing jenis RTH publik eksisting pada Tabel 5.

Tabel 4. Indeks Tutupan Lahan RTH Publik Eksisting di Kota Kotamobagu

\begin{tabular}{clc}
\hline No & Wilayah & Luas (Ha) \\
\hline 1 & Tutupan Lahan & 1.059 \\
2 & Kota Kotamobagu & 6.809 \\
\hline & ITH (\%) & $\mathbf{1 6}$ \\
\hline
\end{tabular}


Tabel 5. ITH Jenis RTH Publik Eksisting di Kota Kotamobagu

\begin{tabular}{|c|c|c|c|}
\hline No & $\begin{array}{l}\text { Jenis RTH Publik } \\
\text { Eksisting }\end{array}$ & $\begin{array}{c}\text { Persentase Luas } \\
\text { Tutupan Lahan } \\
(\%)\end{array}$ & $\begin{array}{c}\text { ITH } \\
(\%)\end{array}$ \\
\hline 1 & Taman Kota: & 0.94 & 0.16 \\
\hline 2 & Lapangan Olahraga: & 0.25 & 0.04 \\
\hline 3 & $\begin{array}{l}\text { Kawasan } \\
\text { Kota }\end{array}$ & 2.4 & 0,37 \\
\hline 4 & $\begin{array}{l}\text { Kawasan Resapan } \\
\text { Air }\end{array}$ & 1.4 & 0,22 \\
\hline 5 & $\begin{array}{l}\text { Jalur Hijau dan } \\
\text { Median Jalan }\end{array}$ & 27.2 & 4,23 \\
\hline 6 & $\begin{array}{l}\text { Sempadan Sungai } \\
\text { dan Mata Air }\end{array}$ & 50.2 & 8 \\
\hline 7 & $\begin{array}{l}\text { Kawasan } \\
\text { Alam }\end{array}$ & 17.6 & 2,73 \\
\hline & Jumlah & 100 & 16 \\
\hline
\end{tabular}

\section{Pengembangan RTH Publik di Kota Kotamobagu}

Dengan melihat hasil interpretasi citra satelit, Indeks Tutupan Lahan (ITH) untuk RTH publik di Kota Kotamobagu belum mencapai standar Indeks Kualitas Lingkugan Hidup (IKLH) yang baik atau hijau. Hal ini ditunjukan dengan nilai ITH yang diperoleh untuk RTH publik di Kota Kotamobagu hanya sebesar $16 \%$. Sedangkan untuk menjadi salah satu kota dengan lingkungan hidup sehat dan hijau, dibutuhkan salah satu indikator IKLH yaitu tutupan lahan/hutan dengan nilai standar 40\%. Luas wilayah Kota Kotamobagu adalah 6.809 ha. Apabila mengacu pada ketentuan 30\% RTH saja maka Kota Kotamobagu telah memenuhi syarat karena luas RTH Kota Kotamobagu sebesar 4.719,08 ha atau sekitar 69,3\% dari luas kota. Namun luas RTH publik Kota Kotamobagu saat ini masih jauh dari yang disyaratkan jika dilihat dari segi pengelolaan. Berdasarkan hasil interpretasi citra satelit tahun 2017 luas RTH publik Kota Kotamobagu adalah 1.059 ha atau sekitar 16\% ITH. Hal ini masih jauh dari persyaratan Indeks Kualitas Lingkungan Hidup yaitu $40 \%$ ITH. Artinya untuk memenuhi standar indikator IKLH ITH, lahan RTH publik masih memiliki kekurangan sekitar 1783 ha atau sekitar 26\% Indeks Tutupan Lahan yang harus dipenuhi. Pengembangan RTH Kota Kotamobagu untuk mendukung Program Pengembangan Kota Hijau $(\mathrm{P} 2 \mathrm{KH})$, sesuai arahan dari Kementerian Pekerjaan Umum tentu saja harus mengacu kepada petunjuk teknis Program Pengembangan Kota Hijau. Menurut Kementerian Pekerjaan Umum (2012), salah satu indikator keberhasilan $\mathrm{P} 2 \mathrm{KH}$ adalah pencapaian luas RTH publik sebesar 20\%. Untuk mengoptimalkan $\mathrm{P} 2 \mathrm{KH}$ yang eksisting, pengembangan RTH publik di Kota Kotamobagu yang ditawarkan dari penelitian ini adalah pemenuhan $20 \%$ luas wilayah RTH publik dan 40\% minimal Indeks Tutupan Lahan (ITH) pada wilayah-wilayah yang dianggap potensi untuk dikembangkan. Beberapa lokasi yang dianggap berpotensi untuk dikembangkan dari segi luas adalah wilayah perkebunan dan sempadan sungai $50 \mathrm{~m}$. Keberadaan lahan perkebunan di Kota Kotamobagu sangat potensial untuk mengubah ruang terbuka hijau.

Tabel 6. Pemenuhan 20\% Luas RTH Publik Eksisting di Kota Kotamobagu

\begin{tabular}{llcc}
\multicolumn{5}{c}{ Kota Kotamobagu } \\
\hline No & \multicolumn{1}{c}{$\begin{array}{c}\text { Pengembangan Jenis RTH } \\
\text { Publik }\end{array}$} & $\begin{array}{c}\text { Luas } \\
(\mathbf{H a})\end{array}$ & $\begin{array}{c}\text { ITH } \\
(\boldsymbol{\%})\end{array}$ \\
\hline 1 & Kawasan hutan kota & 677 & 9.9 \\
2 & Kawasan jalur hijau & 144,7 & 2.1 \\
3 & Kawasan kebun raya & 300 & 4.4 \\
4 & Kawasan agrowisata & 555 & 8.2 \\
5 & Kawasan sempadan sungai 50m & 107,2 & 1.6 \\
\hline & Jumlah & $\mathbf{1 . 7 8 3 , 9}$ & $\mathbf{2 6}$ \\
\hline
\end{tabular}

\section{KESIMPULAN DAN SARAN}

\section{Kesimpulan}

Tutupan Lahan RTH publik di Kota Kotamobagu memiliki nilai Indeks Tutupan Hutan (ITH) sebesar 16\%, kondisi ini dipengaruhi oleh: (1) RTH publik Kota Kotamobagu memiliki luas 1.059 ha (16\%), luas ini belum memenuhi kebutuhan luasan RTH sebagai kota hijau yaitu luas RTH publik minimal 20\%. (2) Terdapat beberapa jenis RTH publik eksisting di Kota Kotamobagu yang pengelolaanya belum optimal seperti Taman Kota Pobundayan, Taman Kota Gelora Ambang, dan Hutan Kota Bonawang. (3) Pengembangan RTH publik di Kota Kotamobagu dititikberatkan pada pemenuhan luas minimal $20 \%$ dari luas wilayah sebagai salah satu indikator kota hijau. Konsep pengembangan meliputi: (1) Penataan RTH publik dari segi letak dan luas. Beberapa lokasi yang dianggap berpotensi untuk dikembangkan dari segi luas adalah wilayah perkebunan, hutan kota dan sempadan sungai 50 m. (2) Peningkatan kualitas RTH melalui peningkatan intensitas vegetasi. Pemilihan jenis vegetasi yang sesuai dengan kriteria dan fungsi RTH publik.

\section{Saran}

Berdasarkan hasil penelitian dan analisis yang dilakukan, saran yang dapat dikemukakan sebagai berikut: (1) perlu adanya kajian lingkungan hidup strategis dan rencana detail tata ruang dan disesuaikan dengan peraturan perundang-undangan. (2) perlu adanya penetapan luas wilayah dan peruntukan RTH publik yang jelas. (3) dalam pemeliharaan 
dan pelestarian RTH perlu adanya kolaborasi antara pemerintah dengan masyarakat.

\section{DAFTAR PUSTAKA}

Abdullah dan Khairuddin. 2009. Jurnal Biocebelebes, hlm 10-19. Emisi Gas Rumah Kaca dan Pemanasan Global. Sulawesi Tengah : Jurusab Fisika Fakultas Matematika dan Ilmu Pengetahuan Alam.

Arifin, H. S. dan Nurhayati. 1996. Penghijauan Kota. Penebar Swadaya, Jakarta.

Aan Komariah danDjam'an Satori. 2012. Metodologi Penelitian Kualitatif. Bandung: Alfabeta.

Arikunto, S. 2009. Manajemen Penelitian. Jakarta: RinekaCipta.

Dadang Supardan. 2000. [dalam Jurnal Pengantar Ilmu Sosial]. Di akses di www. Google.com

B.F. Forman, 1981, "Local Stresses in Vessels Computer Programs for HP- 67 or 97, Pressure Vessel Handbook Publishing, Inc., Tulsa, OK.

C. A. J. Ridd. 1995. Teknologi ELISA dalam diagnosis danpenelitian: Asaihormondengan ELISA. Editor G. W. Burgess. Gajah Mada University Press.Yogyakarta. (Diterjemahkan: W. T. Artamadan E. Moeljono)

Dahlan, E.N., 2007. Analisis Kebutuhan Luasan Hutan Kota sebagai Sink Gas CO2 Antropogenik dari Bahan Bakar Minyak dan Gas di Kota Bogor dengan Pendekatan Sistem Dinamik. Institut Pertanian Bogor.

Dahlan, A. 1991. Hutan Kota untuk Pengelolaan dan Peningkatan Kualitas. Lingkungan Hidup. IPB-APHL. Jakarta.

Fakuara, M. Y. 1987. Hutan Kota Ditinjau dari Aspek Nasional. Seminar Hutan Kota DKI Jakarta.
Grey, G.W. dan F.I. Deneke. 1978. Urban Forestry. John Wiley and Sons.Inc. New York

Hastuti, Elis dan Utami, Titi. 2008. Potensi Ruang Terhuka Hijau dalam Penyerapan CO2 di pemukiman. (Studi kasus: Perumnas Sarjadi Bandung Cerebon).

Murdiyarso. 2003b. CDM : Mekanisme Pembangunan Bersih. Jakarta : Kompas.

Republik Indonesia, 1990. Keputusan Presiden No. 32 Tahun 1990 tentang Pengelolaan Kawasan Lindung. Sekretariat Negara. Jakarta.

Republik Indonesia, 2009. Peraturan Menteri Kehutanana No. P.71/Menhut-II/2009 tentang Pedoman Penyelenggara Hutan Kota. Berita Negara RI Tahun 2009, No. 484. Sekretariat Negara. Jakarta.

Republik Indonesia, 2008. Peraturan Menteri Pekerjaan Umum No. 05/PRT/M/2008 tentang Pedoman dan Pemanfaatan Ruang Terbuka Hijau di Kawasan Perkotaan. Dirjen Penataan Ruang. Departemen Pekerjaan Umum. Jakarta.

Republik Indonesia, 2007. Peraturan Menteri Dalam Negeri No. 1 Tahun 2007 tentang Penataan Ruang Ruang Terbuka Hijau Kawasan Perkotaan. Departemen Dalam Negeri. Jakarta.

Republik Indonesia, 1993. Peraturan Menteri Pekerjaan Umum No. 63/PRT/1993 tentang Garis Sempadan dan Sungai, Daerah Manfaat Sungai, Daerah Penguasaan Sungai dan Bekas Sungai. Dirjen Penataan Ruang. Departemen Pekerjaan Umum. Jakarta.

Republik Indonesia, 2002. Peraturan Pemerintah No. 63 Tahun 2002 tentang Hutan Kota. Lembaran Negara RI Tahun 2002, No. 119. Sekretariat Negara. Jakarta.

Walikota Kotamobagu 2014. Peraturan Daerah Kota Kotamobagu No. 8 Tahun 2014 tentang Rencana Tata Ruang Wilayah Kota Kotamobagu 2014-2034. Kota Kotamobagu. Provinsi Sulawesi Utara. 